\title{
POTENSI PENDIDIKAN HAK ASASI MANUSIA DALAM MEMPERSIAPKAN SISWA DALAM KONTEKS KERAGAMAN BUDAYA
}

\author{
Muhammad Khairil Mustofa \\ Pusat Studi Islam Multikultural \\ Email : khairilmustofa617@gmail.com
}

\begin{abstract}
Abstrak
Pendidikan hak asasi manusia sangat diperlukan dalam mempersiapkan siswa yang hidup dalam konteks masyarakat multikultural. Pendidikan hak asasi manusia mempunyai potensi besar memberikan kontribusi mendasar dalam menanamkan prinsip-prinsip demokrasi dan hak asasi manusia bagi siswa. Namun lingkungan sekolah yang menjadi tempat pelaksanaan pendidikan hak asasi manusia memiliki persoalan dan tantangan tersendiri yang berpotensi menghambat terlaksananya pendidikan hak asasi manusia. Sehingga diperlukan komitmen kuat dari sekolah untuk memaksimalkan potensi pendidikan hak asasi manusia dengan menciptakan lingkungan sekolah yang kondusif bagi terlaksananya prinsip-prinsip demokrasi atas dasar hak asasi manusia.
\end{abstract}

Kata Kunci: hak asasi manusia, demokrasi, partisipasi,

\section{Abstract}

Human rights education is indispensable in preparing students who live in the context of a multicultural society. Human rights education has great potential to make a fundamental contribution in imparting the principles of democracy and human rights for students. However, the school environment where human rights education is implemented has its own problems and challenges that have the potential to hinder the implementation of human rights education. So it requires a strong commitment from schools to maximize the potential of human rights education by creating a school environment that is conducive to the implementation of democratic principles based on human rights.

Keywords: human rights, democracy, participation,

\section{PENDAHULUAN}

Pendidikan hak asasi manusia menegaskan komitmen untuk menghargai, menghormati, melindungi hak-hak setiap manusia. Dalam UUD 1945 pasal $28 \mathrm{~J}$ ayat 1 disebutkan bahwa "setiap orang wajib menghormati hak asasi manusia orang lain dalam tertib kehidupan 
bermasyarakat, berbangsa dan bernegara”. Dan diperkuat oleh UUD 1945 pada pasal 28 A, yang berbunyi, "setiap orang berhak untuk hidup serta berhak mempertahankan hidup dan kehidupannya”. Pasal $28 \mathrm{C}$ ayat 1 berisi tentang setiap orang yang berhak mengembangkan diri melalui pemenuhan kebutuhan dasar, berhak mendapatkan pendidikan, dan mendapatkan manfaat dari ilmu-ilmu dan teknologi, seni dan budaya, demi meningkatkan kualitas hidup dan kesejahteraan.

Landasan pemikiran tentang pentingnya pendidikan hak asasi manusia terdapat dalam pasal 26 (2) Deklarasi Universal Hak Asasi Manusia.

"Pendidikan harus diarahkan pada pengembangan sepenuhnya kepribadian manusia dan untuk memperkuat penghormatan terhadap hak asasi manusia dan kebebasan fundamental. Harus meningkatkan pengertian, toleransi dan persahabatan antara semua bangsa, ras atau kelompok agama, dan melanjutkan kegiatan PBB untuk memelihara perdamaian "

Mandat Pasal 26 (2) ini pada dasarnya adalah untuk mengembangkan hak asasi manusia hanya dapat dicapai melalui pendidikan. UNESCO juga menegasakan bahwa "pendidikan hak asasi manusia merupakan bagian integral dari hak atas pendidikan dan semakin mendapatkan pengakuan sebagai hak asasi manusia itu sendiri". ${ }^{1}$ Secara lebih khusus, PBB Hak Asasi Manusia telah mempromosikan pendidikan hak asasi manusia dalam Resolusi 2004/71:

"Pendidikan hak asasi manusia adalah sebuah proses jangka panjang dan seumur hidup dimana semua orang di semua tingkat pembangunan dan di semua strata masyarakat belajar menghormati martabat orang lain dan cara dan metode untuk memastikan bahwa menghormati dalam semua masyarakat ... (itu) memberikan kontribusi signifikan untuk mendorong kesetaraan dan pembangunan berkelanjutan, mencegah konflik dan pelanggaran hak asasi manusia dan meningkatkan partisipasi dan proses demokrasi, dengan tujuan untuk mengembangkan masyarakat di mana semua hak asasi manusia dihargai dan dihormati "(dikutip dalam UNESCO, 2009).

\section{PEMBAHASAN}

\section{Pendidikan Hak Asasi Manusia}

Pendidikan hak asasi manusia adalah upaya-upaya yang dilakukan secara sadar dan tersistem untuk membangun kesadaran siswa tentang hak-

${ }^{1}$ UNESCO, (2009). Promotion of Human Rights Education. Retrieved 23 May 2009, from http://www.unescobkk.org/education/appeal/programmethemes/education-and-human-rights/human-rights-education/ 
hak individu serta tentang tanggung jawab untuk menghormati hak-hak orang lain. Hak asasi manusia adalah tentang "pentingnya martabat manusia secara pribadi, kesetaraan hak dan tanggung jawab timbal balik untuk menjamin hak orang lain yang dihormati". ${ }^{2}$

UNESCO secara luas mendefinisikan pendidikan hak asasi manusia sebagai sebuah proses belajar dan pelaksanaan hak asasi manusia itu sendiri. Ini berarti bahwa pendidikan hak asasi manusia tidak hanya tentang transmisi konten, tetapi menerjemahkan prinsip-prinsip dalam praktek. Pendidikan hak asasi manusia juga mempromosikan nilai-nilai kesetaraan, perdamaian, non-diskriminasi, non-kekerasan, toleransi dan penghormatan terhadap martabat manusia. Dengan demikian pendidikan hak asasi manusia merupakan bagian penting dalam mempersiapkan siswa untuk kewarganegaraan dimana siswa belajar dan berpengalaman bagaimana untuk hidup dalam masyarakat atas dasar hak asasi manusia. Dalam hal ini, pendidikan hak asasi manusia memberikan potensi nyata untuk pengembangan kewarganegaraan yang demokratis. Sehingga mendidik siswa tentang hak asasi manusia adalah agenda penting untuk mewujudkan masyarakat yang demokratis atas dasar menghormati hak asasi manusia.

\section{Kewarganegaraan dan Demokrasi}

Konsep kewarganegaraan adalah mengakui individu sebagai aktor di pemerintahan yang demokratis dan membutuhkan penerimaan hak asasi manusia, yang menawarkan kerangka kerja esensial yang menjamin hak-hak semua individu dihormati sebagai martabat dan kebebasan fundamental mereka dalam demokrasi seperti yang dinyatakan dalam pasal 12 - 16 dari Konvensi Hak Anak tentang hak-hak pikiran, hati nurani dan agama; asosiasi, ekspresi, gerakan, memiliki properti, perkawinan dan kehidupan keluarga. ${ }^{3}$ Karena gagasan kewarganegaraan didasarkan pada konsep kesetaraan dan keragaman dimana semua individu merupakan pemegang hak asasi manusia yang sama, maka demokrasi dan hak asasi manusia adalah dua aspek penting dalam pelaksanaan kewarganegaraan. Hal Ini berarti bahwa prinsip-prinsip demokrasi dalam praktek kewarganegaraan tidak hanya tentang hak-hak individu, tetapi itu adalah tentang menghormati hak orang lain berdasarkan nilai-nilai universal kemanusiaan.

Agenda utama dari pendidikan kewarganegaraan adalah tentang hubungan manusia di dalam individu dan antara kelompok-kelompok yang

${ }^{2}$ Osler, A. and Starkey, H. (2005). Changing Citizenship: Democracy and Inclusion in Education. Maidenhead: Open University Press.

${ }^{3}$ Osler, A. and Starkey, H. (2005). Changing Citizenship: Democracy and Inclusion in Education. Maidenhead: Open University Press. 
merupakan bagian penting dari demokrasi. Tibbits menegaskan bahwa tujuan utama pendidikan untuk kewarganegaraan paling erat berhubungan dengan "belajar untuk hidup bersama". ${ }^{4}$ Demokrasi menawarkan "ruang politik" bagi individu untuk memiliki kebebasan untuk menikmati hak-hak mereka, tetapi pada saat yang sama mereka memiliki tanggung jawab untuk menjamin kebebasan orang lain untuk melaksanakan hak mereka juga (Osler dan Starkey (2005). Dengan kata lain, setiap warga negara diberikan kesempatan untuk belajar dari satu sama lain dan untuk berbagi tentang "nilai-nilai dan prioritas-prioritas"

Pendidikan hak asasi manusia merupakan strategi penting untuk mencapai tujuan penting dalam konsep belajar untuk hidup bersama. Pendidikan hak asasi manusia akan membantu siswa untuk menjadi warga negara yang terdidik dan berkomitmen terhadap nilai-nilai hak asasi manusia dan tanggung jawab sosial sehingga siswa mempunyai kapasitas untuk berpartisipasi dalam demokrasi di semua tingkatan, mulai lokal, nasional sampai internasional. Dengan kata lain, pendidikan hak asasi manusia adalah pendidikan untuk kewarganegaraan yang cenderung berevolusi "kesadaran individu dan kelompok tentang hak-hak mereka dan tanggung jawab sebagai warga negara, kesadaran dan komitmen terhadap hak asasi manusia dan kebebasan, kesetaraan, aturan hukum dan pluralisme". Sehingga pendidikan hak asasi manusia memberikan kerangka kerja penting untuk mencapai hubungan sosial yang harmonis dan stabil, di mana hak-hak semua warga negara dengan latar belakang budaya yang beragam dihargai dan dihormati.

\section{Lingkungan Sekolah dan Partisipasi Siswa}

Sekolah tampaknya menjadi alasan yang paling mendasar dalam pendidikan kewarganegaraan. Argumennya adalah bahwa komunitas sekolah terdiri dari sekelompok orang dengan budaya yang berbeda dan keyakinan yang mencerminkan sebuah komunitas masyarakat. Menurut Schnappersekolah berpotensi menjadi model untuk negara demokrasi yang ia sebut sebagai "sebuah komunitas warga".

"Sekolah ini tidak hanya untuk mentransmisikan ideologi nasional dan memori sejarah umum melalui kurikulum. Pada tingkat yang lebih dalam, seperti bangsa politik, sekolah membentuk ruang dibangun di mana siswa,

${ }^{4}$ Tibbits, F. (2005). Literature Review on Outcomes of School-Based Programs Related to "Learning To Live Together". UNESCO. Retrieved 12 June 2009, from http: //www.hrusa.org/workshops/ HREWorkshops/usa/UNESCO_Lit Review_ProgramSummary.doc. 
seperti warga, diperlakukan sama, terlepas dari keluarga mereka atau latar belakang sosial. Ini adalah tempat, baik secara harfiah dan sebagai sebuah konsep, yang dibangun bertentangan dengan ketidaksetaraan nyata dan ada masyarakat yang menonjol melawan kekuatan diskriminasi yang ditemukan dalam masyarakat sipil. Konsep sekolah, seperti konsep kewarganegaraan, impersonal dan formal. Dengan memahak asasi manusiai gagasan sekolah sebagai komunitas, anak-anak akan belajar untuk memahak asasi manusiai dan merasa dilibatkan di negara politik "5

Tidak diragukan lagi bahwa sekolah memiliki potensi untuk menumbuhkan lingkungan yang kondusif untuk menegakkan prinsip-prinsip hak asasi manusia dalam mewujudkan masyarakat yang demokratis.

Pada dasarnya yang diperlukan untuk kekuatan demokrasi adalah membangun budaya hak asasi manusia di mana semua individu dengan beragam budaya dapat berpartisipasi dalam pengambilan keputusan (Osler, 2005). Pendidikan hak asasi manusia di lingkungan sekolah akan mampu mendorong terbangunnya budaya hak asasi manusia. Pemahaman dan pengalaman hak asasi manusia di sekolah akan membantu siswa untuk mempratekkan kewarganegaraan dan prinsip-prinsip demokrasi secara nyata dalam konteks komunitas sekolah. Ini berarti bahwa sekolah perlu mengenali siswa sebagai warga negara saat ini, bukan hanya mempersiapkan mereka untuk kewarganegaraan masa depan di mana sekolah mendukung pengembangan identitas siswa yang beragam serta menjamin hak partisipasi mereka sebagai warga negara untuk ambil bagian dalam kebudayaan, urusan ekonomi dan politik di masyarakat luas.

Partisipasi merupakan sarana kunci untuk membangun demokrasi dan mengukur demokrasi. Pendidikan hak asasi manusia harus mampu menjadi sarana untuk meningkatkan kapasitas dan ketrampilan siswa untuk berpartisipasi dalam pengambilan keputusan di sekolah dan mengembangkan nilai-nilai demokrasi dan penghormatan terhadap hak asasi manusia, misalnya melalui advokasi, konseling dan keterampilan mendengarkan, resolusi konflik. Dengan demikian siswa harus diberikan kesempatan untuk berlatih secara aktif menggunakan hak-hak partisipasi mereka dalam pengambilan keputusan dan tanggung jawab di sekolah dalam rangka mempersiapkan mereka untuk kewarganegaraan dalam "sebuah masyarakat demokratis yang bebas".

Inti dari setiap masyarakat demokratis perlu "kolaborasi produktif" antara anak dan orang dewasa untuk peningkatan kualitas demokrasi itu

5 Osler, A. and Starkey, H. (2002). Teacher Education and Human. London: David Fulton. 
sendiri. Dalam hal ini, keterlibatan orang dewasa adalah penting dipertimbangkan untuk dapat berpartisipasi sama-sama aktif bersama dengan anak-anak. Ini berarti bahwa orang dewasa sebaiknya tidak hanya menawarkan bimbingan bagi siswa untuk berpartisipasi, tetapi juga mereka harus mengambil pelajaran dari keterlibatan aktif mereka dalam proses partisipasi.

\section{Problematika Pendidikan Hak Asasi Manusia di Sekolah}

Ada klaim bahwa sekolah adalah tempat yang layak anggota komunitas sekolah untuk melaksanakan fungsi kewarganegaraan dengan menerapkan prinsip-prinsip demokrasi atas dasar hak asasi manusia dan keadilan sosial. Osler dan Starkey berpendapat bahwa praktek kewarganegaraan harus lebih diterapkan dalam kompleksitas masyarakat yang lebih luas, dan sekolah adalah "mikrokosmos masyarakat"dari beragam populasi global. Namun, klaim bahwa sekolah adalah "masyarakat mikrokosmos" masih dipertanyakan. Pertanyaannya bukan pada apakah sekolah memiliki potensi sebagai representasi kepentingan masyarakat yang lebih luas di luar sekolah, namun sejauh mana pemahaman guru tentang tanggung jawab mereka di masyarakat serta seberapa besar kapasitas mereka dalam mengintegrasikan isu-isu isu-isu hak asasi manusia dan demokrasi dalam konteks sekolah.

Persepsi guru tentang hak asasi manusia memainkan peran penting dalam transmisi pengetahuan tentang hak asasi manusia. Menurut Wilkin persepsi guru banyak dipengaruhi oleh ideologi, pemahaman dan pengalaman pribadi mereka tentang isu-isu hak asasi manusia. Wilkin memberikan contoh mengenai rasisme dimana guru mengalami akan mengalami kesulitan dalam mengatasi diskriminasi struktural dalam pendidikan jika persepsi mereka tentang diskriminasi tetap berakar pada domain pribadi mereka. Wilkins menemukan masih banyaknya guru yang gagal dalam melibatkan diri secara penuh dalam proses sosial yang menyebabkan dan memperkuat perbuatan rasisme mereka, meskipun mereka memahami bahwa mereka bertanggung jawab untuk mengajarkan nilai-nilai kesetaraan ras. Dalam sebuah penelitian yang dilakukan di Nigeria dalam bidang partisipasi hak-hak anak mencontohkan bagaimana para pembuat kebijakan dan administrator sekolah seperti guru dan kepala sekolah tidak mengizinkan siswa mereka khususnya di sekolah-sekolah dasar untuk berpartisipasi dalam membuat aturan dan peraturan yang 
memiliki efek pada kehidupan mereka di sekolah karena diyakini bahwa siswa tidak mampu membuat keputusan secara rasional. ${ }^{6}$

Selain itu, sekolah belum mampu menyediakan bahan yang cukup untuk pendidikan hak asasi manusia dalam menangani masalah masyarakat global. Fakta bahwa siswa sebagai warga negara harus menyadari masalah utama dari masyarakat global seperti ketidakadilan, kemiskinan, ketidaksetaraan, kelaparan, konflik dan perang, diskriminasi, rasisme, xenofobia. Namun dalam banyak kasus, sekolah masih mengalami kesulitan untuk menemukan cara mengajar hak asasi manusia yang terkait dengan isuisu global sesuai dengan konteks sekolah (Senarclens, 1983). Hal ini karena "kurangnya materi pendidikan yang sesuai adalah alasan yang diberikan oleh banyak pendidik untuk kegagalan mereka berurusan dengan isu-isu global dan hak asasi manusia" (Buergenthal dan Torney (1976), dikutip dalam Tarrow, 1991, hal: 197).

Masalah lainnya berasal dari administrator sekolah yang memiliki kewenangan untuk menentukan subyek hak asasi manusia termasuk dalam kurikulum sekolah mereka. Sebuah penelitian menunjukkan bahwa guru umumnya enggan untuk mencakup topik-topik berisiko. Sehingga guru merasa tidak percaya diri untuk mengangkat isu-isu kontroversial hak asasi manusia dan demokrasi dengan murid karena mereka tidak tahan terhadap reaksi masyarakat. Seringkali seorang guru harus mendapatkan persetujuan resmi dari administrator sekolah untuk menyampaikan isu-isu kontroversial di dalam kelas (Tarrow, 1991)

Pendidikan hak asasi manusia di sekolah harus melekat dengan kepentingan holistik dari masyarakat yang lebih luas. Sehingga sekolah perlu melakukan perubahan organisasi yang yang lebih terbuka kepada masyarakat luas untuk efektivitas pembelajaran kewarganegaraan.

\section{Tantangan Pendidikan Hak Asasi Manusia di Sekolah}

Pertanyaan kunci selanjutnya adalah apakah pendidikan hak asasi manusia dapat diterjemahkan ke dalam lingkungan sekolah? Ada tiga elemen penting yang diperlukan dalam proses pendidikan hak asasi manusia di sekolah karena mereka berevolusi selama proses belajar, yaitu dalam memberikan pengetahuan, pembentukan sikap, dan mengasah keterampilan

6 Ejieh, M.U.C. and Akinola, O.B. (2009) 'Children's Rights and Participation in Schools: Exploring the Awareness Level and Views of Nigerian Primary School Children', Elementary Education Online, vol.8, no.1, pp.176-182 
siswa. ${ }^{7}$ Pendidikan hak asasi manusia bagaimanapun tidak hanya untuk mendapatkan proses kognitif, tetapi juga memberi siswa kesempatan untuk menggunakan hak-hak mereka dalam konteks demokrasi, keadilan sosial dan masyarakat sipil. Dengan demikian pendidikan hak asasi manusia bukan hanya tentang pengetahuan tetapi juga tentang pembentukan sikap dan implementasinya.

Ketiga elemen tersebut merupakan komponen penting untuk mempersiapkan siswa untuk terlibat dengan persoalan-persoalan nyata di masyarakat. Namun, sekolah-sekolah cenderung sulit untuk memahami tiga unsur penting tersebut sekaligus. Selama ini sebagian besar sekolah hanya memasukkan aspek kognitif dalam mengajarkan pendidikan hak asasi manusia, seperti pengetahuan tentang pra-syarat minimum sebagai warga negara. Sedangkan dua aspek yang lain yaitu afektif dan kognitif masih belum mampu dijangkau. ${ }^{8}$ Beberapa contoh kasus membuktikan bahwa komunitas sekolah tidak bersedia untuk melakukan lebih daripada pendekatan minimal untuk mengembangkan kewarganegaraan dalam konteks sekolah. Oleh karena sekolah perlu menyesuaikan diri dalam rangka memberikan konteks yang tepat bagi siswa untuk mendapatkan pengetahuan tentang hak asasi manusia serta mampu bersikap dan berperilaku yang tidak bertentangan dengan hak asasi manusia.

\section{KESIMPULAN}

Pertama, pendidikan hak asasi manusia potensi tinggi untuk mempersiapkan siswa untuk kewarganegaraan dalam masyarakat budaya yang beragam, namun pendidikan hak asasi manusia memiliki potensi yang relatif rendah dalam realisasinya.

Kedua, pendidikan hak asasi manusia masih memerlukan pendekatan holistik dengan menggabungkan ketiga komponen; kognitif, afektif, dan psikomotorik, secara bersama-sama, sehingga mampu mengontekstualisasikan pendidikan hak asasi manusia ke dalam kehidupan

${ }^{7}$ Eide, A. (1983). Globalization Human Rights Education. In Eide, A. and Thee, M. (Ed.), Frontiers of Human Rights Education (pp.1-6). Oslo: Universitetsforlaget.

${ }^{8}$ Audigier, F. (1991). Socialization and Human Rights Education - The Example of France. In Starkey, H. (Ed.), Socialisation of School Children and Their Education for Democratic Values and Human Rights: Report of the Colloquy of Directors of Educational Research Institutions Held in Ericeira (Portugal) on 17-20 October 1989 (pp.129-148). Oxford: Swets and Zeitlinger. 
nyata masyarakat. Oleh karena itu, sekolah perlu lebih memperhatikan peran guru dalam pendidikan hak asasi manusia dengan membekali mereka dengan konten dan metode serta proses pengajaran pendidikan hak asasi manusia. Sekolah juga harus mampu menyediakan saran dan prasarana yang memadai guna mewujudkan lingkungan sekolah yang demokratis atas dasar hak asasi manusia. Sehingga siswa akan mempunyai kemampuan dan kesadaran yang tinggi atas hak-hak dan kewajiban kewarganegaraan mereka dalam masyarakat yang beragam budaya.

\section{DAFTAR PUSTAKA}

Audigier, F. (1991). Socialization and Human Rights Education - The Example of France. In Starkey, H. (Ed.), Socialisation of School Children and Their Education for Democratic Values and Human Rights: Report of the Colloquy of Directors of Educational Research Institutions Held in Ericeira (Portugal) on 17-20 October 1989 (pp.129-148). Oxford: Swets and Zeitlinger.

Eide, A. (1983). Globalization Human Rights Education. In Eide, A. and Thee, M. (Ed.), Frontiers of Human Rights Education (pp.1-6). Oslo: Universitetsforlaget.

Ejieh, M.U.C. and Akinola, O.B. (2009) 'Children's Rights and Participation in Schools: Exploring the Awareness Level and Views of Nigerian Primary School Children', Elementary Education Online, vol.8, no.1, pp.176-182

http://www.coe.int/t/dg4/education/edc/Source/Pdf/Documents/2000_16_Str ategies4LearningEDC.pdf

https://education.uw.edu/sites/default/files/cme/docs/pdf/_notes/DEMOCR ACY\%20AND\%20DIVERSITY\%20pdf.pdf

https://www.unicef-irc.org/publications/100-childrens-participation-fromtokenism-to-citizenship.html

Osler, A. and Starkey, H. (2000). Citizenship, Human Rights and Cultural Diversity. In Audrey Osler (Ed.) Citizenship Democracy in Schools: Diversity, Identity, Equality (pp.3-17). Staffordshire and Sterling: Trenthak asasi manusia Books Limited.

Osler, A. and Starkey, H. (2002). Teacher Education and Human. London: David Fulton.

Osler, A. and Starkey, H. (2005). Changing Citizenship: Democracy and Inclusion in Education. Maidenhead: Open University Press.

Pais, M.S. (2000) 'Child Participation', Documentacao e Direito Comparado, 05 (81/82), pp. 93 - 101. New York: UNICEF. 
Senarclens, P. (1983). Research and teaching of Human Rights: Introduction Remarks. In In Eide, A. and Thee, M. (Ed.), Frontiers of Human Rights Education (pp.7-14). Oslo: Universitetsforlaget.

Starkey, H. (1991). The Council of Europe Recommendation on the Teaching and Learning of Human Rights in Schools. In Starkey, H. (Ed.), The Challenge of Human Rights Education (pp.20 - 38). London: Cassel.

Tarrow, N. (1991). United State of America Human Rights Education: Alternative Conceptions. In Starkey, H. (Ed.), Socialisation of School Children and Their Education for Democratic Values and Human Rights: Report of the Colloquy of Directors of Educational Research Institutions Held in Ericeira (Portugal) on 17-20 October 1989 (pp.183-204). Oxford: Swets and Zeitlinger.

Tibbits, F. (2005). Literature Review on Outcomes of School-Based Programs Related to "Learning To Live Together". UNESCO. Retrieved 12 June 2009, from

http://www.hrusa.org/workshops/HREWorkshops/usa/UNESCO_LitReview ProgramSummary.doc

Undang-Undang Dasar Negara Republik Indonesia 1945, Penjelasan Umum.

UNESCO, (2009). Promotion of Human Rights Education. Retrieved 23 May 2009, from http: //www.unescobkk.org /education/ appeal/ programme-themes/education-and-human-rights/human-rightseducation/

Wilkins, C. (2005). Teaching for Equality and Diversity: Putting Values into Practice. In Osler, A. (Ed.), Teachers, Human Rights and Diversity: Educating Citizens in Multicultural Societies (pp.155-170). Stoke on Trent: Trenthak asasi manusia Books. 